\title{
TECHNICAL ANALYSIS: THE ROLE OF INVESTOR PSYCHOLOGY MEDIATING ON STOCK INVESTMENT BEHAVIOR
}

\author{
Nur Asmilia \\ University of Pamulang \\ Nurasmilia30@gmail.com
}

\begin{abstract}
The purpose of this study is to prove empirically whether the technical factors represented by stock price indicators, trading volume and market capitalization have an influence on investor psychology. In addition, it is also to determine the effect of investor psychology on the behavior of stock investment. The number of data samples in this study that is as many as 108 respondents from the population of investors who have been chosen as the object of research. The sampling technique in this study is random sampling. The use of the technique is due to the population that is unknown to the researcher. Testing the hypothesis is tested by structural equation modeling. The results showed that stock prices, trading volume and market capitalization have a significant influence on investor psychology, and investor psychology is known to have a significant effect on stock investment behavior.
\end{abstract}

Keywords: Stock Price, Trading Volume, Market Capitalization, Investor Psychology and Behavior of Stock Investments

\section{INTRODUCTION}

Investment is the placement of money or funds in the hope of obtaining economic benefits in the future. The purpose of investing is to make a profit. Investments can be made not only in the real sector but also in the financial sector in the form of purchasing securities such as Bank Indonesia Certificates, bonds and shares. Purchasing securities such as stocks can be done in the capital market. Capital markets carry out two functions at once, economic functions and financial functions. Economic function because the market provides facilities or vehicles that bring together two interests, namely those who have excess funds (investors) and those who need funds (issuers). Financial function because the capital market provides the possibility and opportunity to get a return for the owner of the fund according to the characteristics of the chosen investment. Every investor has a different way of choosing an analytical method to consider choosing an investment decision in selling or buying shares. There are two kinds of analytical methods, namely fundamental analysis and technical analysis.

In the development of modern investment, investment decisions seem to rely more on technical analysis than fundamental analysis.

According to Meyers (1994), this occurs because securities price movements are no longer random but rather and form certain patterns that can be identified. But this is actually a 
decision choice for an investor. This technical analysis aims to quickly find price trends, estimate the likelihood of time and distance of the trend and choose the most profitable time to enter and exit the market. With this, investors who are always on standby will observe any price movements so that they have the chance to gain profits when prices rise or fall. However, along with the development of time there is a shift in the tendency of investors to determine investment decisions based on aspects of

\section{LITERATURE REVIEW}

\subsection{Technical Analysis}

Technical analysis is a method of evaluating stocks, commodities or other securities by analyzing statistics produced by market activity in the past in order to predict future price movements (Edianto, 2011).

\subsection{Stock Price}

The stock price is the price of a stock at a certain time determined by market participants and by the demand and supply of the shares in question in the capital market. At certain times it means that at any time the stock price can change.

\subsection{Trading Volume}

Trading volume is the amount of volume of shares traded. Trading volume indicates convenience in trading these shares. Changes in stock trading volume on the capital market show stock trading activities on the stock exchange and reflect investors' investment decisions.

\subsection{Capitalization Market}

Fakhruddin (2008) defines market capitalization as the value of the amount of public companies that have listed their shares on the stock exchange. In psychology that can affect investor behavior. Psychological factors of investors can have a big influence not only in determining the type of investment to be chosen, but also in the subsequent attitudes in responding to various events. The value, all of that will have an effect on investment returns. Psychological factors should be understood by all investors so that at least whatever is done is a conscious choice. Not an unconscious attitude.

general, large capitalized shares are the target of investors for long-term investment because of the company's amazing growth potential in addition to dividend distribution and relatively low risk exposure.

\subsection{Investor Psychology}

Investor psychology is an atmosphere or something within oneself that is felt when making transactions on the stock market, investor psychology is the most important thing in investing.

\subsection{Investment Behavior}

Investment behavior is defined as how investors decide, explain, analyze and review procedures for decision making, which include investment psychology, information gathering, defining and understanding, researching and analyzing. This whole process is referred to as "Investment Behavior" (Slovic, 1972; Alfredo and Vicente, 2010).

\section{RESEARCH METHOD}

The sampling technique used is simple random sampling. Simple random sampling according to Sugiyono (2001) is stated to be simple because sampling of population members is done randomly regardless of the strata that 
exist in that population. The number of data samples in this study that is as many as 108 respondents from the population of investors who have been chosen as the object of research.

In this sub-section, the definitions of each variable are used in the research, namely: variable stock prices, trading volume variables, market capitalization variables, investor psychology variables and investment behavior variables. Details about each variable used in this study are:

1. Exogenous Variables: Stock Prices, Trading Volume and Market Capitalization.

2. Intervening Variables: Investor Psychology.

3. Endogenous Variables: Investment Behavior

All variables in this study were obtained through primary data collection using a questionnaire distributed through Google doc to investors who were the object of this research.

\section{RESULTS AND DISCUSSION 4.1 Test of Reliability and Validity}

Reliability test is done by calculating Cronbach alpha from each item in a variable. An instrument in a variable is said to be reliable, if it has a Cronbach alpha greater than 0.6 , while Cronbach alpha in this study are as follows: technical factors amounting to 0.773 , investor psychology is 0.774 and investment behavior is 0.824 . With the results of these tests it can be concluded, that the instruments used in the study are reliable.

Validity test is done by calculating cronbach alpha from each item in a variable. An instrument in a variable is said to be valid, if it has cronbach alpha greater than the r-table value is 0.361 , while cronbach alpha in this study is as follows: technical factors amounting to
0.448 , investor psychology at 0.447 and investment behavior at 0.549 . With the results of these tests it can be concluded, that all statements have been declared valid. Therefore, question items from the set of variables can be used as instruments for data collection.

\subsection{Normality Test}

Data that is normally distributed is indicated by the value c.r. (critical ratio) per indicator and multivariate between 2.58 to +2.58 and vice versa if the data is not normal. The test results show that the multivariate value is 2.526 so that it can be said that the data is normally distributed.

\subsection{Measurement Model}

The measurement model aims to test how precisely the indicator variables can explain the factors that exist. The test was carried out by measuring convergent validity of factors with their indicators through confirmatory factor analysis. After the model is known to be valid, the process is then followed by a test of goodness of fit. The following are presented by AMOS processing results for confirmatory factor analysis on each factor and its indicators:

Testing for confirmatory factor analysis explains that all indicators show numbers above the criteria of 0.07 so that the data can be said to be valid. After the convergent validity of all variables is known, the next step is to assess the model's goodness of fit.

\subsection{Testing the Overall Goodness of Fit}

The testing of goodness of fit in the overall model aims to determine the level of compatibility between the sample covariance matrix and the population covariance matrix. The test results were measured through several measurement indices namely Chi- 
Square, Probability, RMSEA, GFI, table which is the result of testing the AGFI, TLI, and CFI. The following is a overall goodness of fit model:

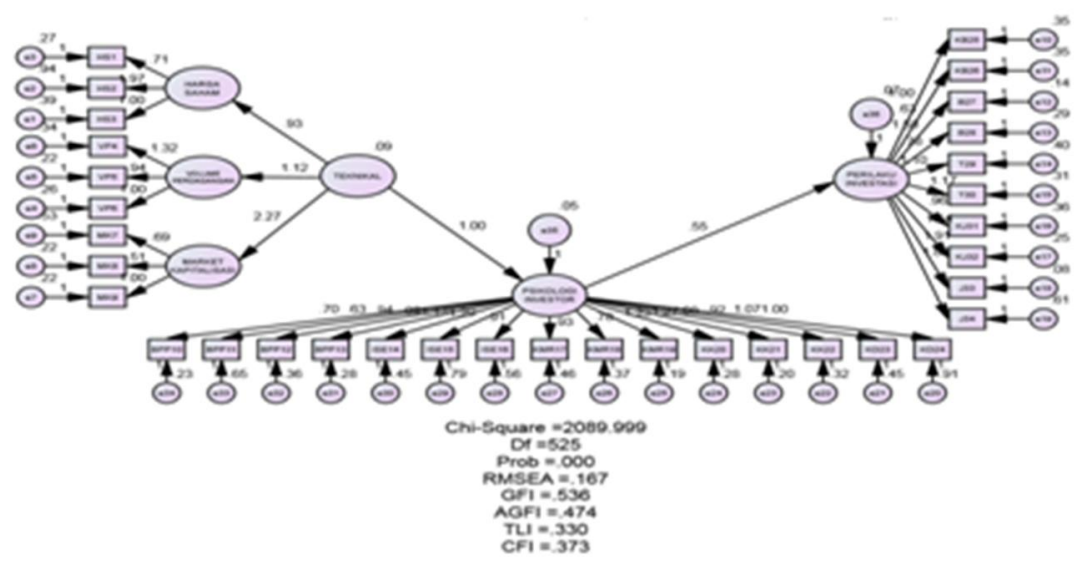

Figure 1. Goodness of Fit Research Model

Table 1. Goodness of Fit Structural Model Testing Results

\begin{tabular}{|lccc|}
\hline \multicolumn{1}{|c}{ Criteria } & Result & Cut of Value & $\begin{array}{c}\text { Model } \\
\text { Assessment }\end{array}$ \\
\hline Chi-Square & 2089,999 & It is expected to be smaller & Good \\
Probability & 0.000 & $\geq 0,05$ & Marginal \\
RMSEA & 0.167 & $\leq 0,08$ & Marginal \\
GFI & 0,536 & $\geq 0,90$ & Marginal \\
AGFI & 0,474 & $\geq 0,90$ & Marginal \\
TLI & 0,330 & $\geq 0,95$ & Marginal \\
CFI & 0,373 & $\geq 0,94$ & Marginal \\
\hline
\end{tabular}

Source: AMOS Processed Products Ver. 22 
The calculation result of Chi-square is equal to 2089,999 . It can be said to be good because it fulfills the multivariate normality assumption. While the value of RMSEA based on the above table is equal to 0.167 , the value is above the range of values $\geq 0.08$. Then for the GFI value of 0.536 , the AGFI value is 0.474 , the TLI value is 0.330 and the CFI value of 0.373 is still below the cut-off value. it can be said that the model is good enough because it is still in the marginal range so that the model is feasible to use in testing hypotheses..

\subsection{Discussion}

Hypothesis testing aims to determine the causality relationship between exogenous variables and endogenous variables in a study. The regression weight test results can be seen in table 2.

Table 2. Regression Weights Test Results

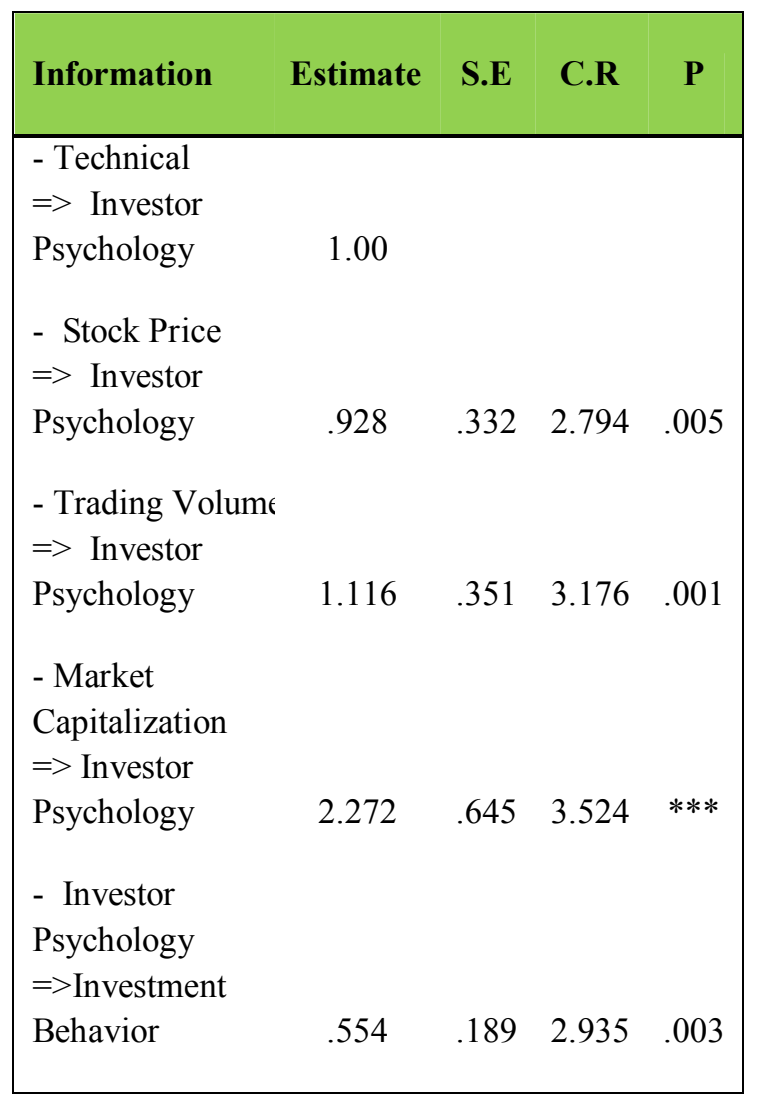

Testing the causality hypothesis developed in this model can be seen in the table above. The effect of each exogenous variable on endogenous is known by comparing the results of the probability test $(p)$ with the cut-off probability vaule of 0.05 , the explanation is as follows:

H1: There are influences of exogenous variables on endogenous variables (If $p$ value is $\leq 0.05$ )

H0: There is no influence of exogenous variables on endogenous variables (If $p$ value is $\geq 0.05$ )

\subsubsection{Effect of Stock Prices on Investor Psychology}

The results of the stock price testing on investor psychology show that the $\mathrm{P}$ value is $0.005 \leq 0.05$, where the test decision is to accept the $\mathrm{H} 1$ hypothesis. Based on the results of these tests, it can be concluded that statistically the stock price variable has a significant positive effect on investor psychology.

This is because investors' perceptions of market conditions cause stock price movements to fluctuate in a certain range. When investors consider the market in a bullish condition they tend to make a lot of purchases so that prices continue to crawl up to reach the highest point and vice versa when the market is in a bearish condition, investors tend to make a lot of sales so that prices are depressed to the lowest point.

\subsubsection{Effect of Trading Volume on Investor Psychology}

The results of testing the effect of trading volume on investor psychology, indicate that the $\mathrm{P}$ value obtained is smaller than the $\mathrm{P}$ cut-off value $(0.001 \leq$ 0.05 ). The test results based on the sample data carried out state the rejection of $\mathrm{H} 2$ or in other words accept $\mathrm{H} 2$. So it can be concluded that 
statistically or inferentially there is a significant positive effect of trading volume on investor psychology.

The results of the hypothesis show that trading volume is important in influencing investor psychology. Because trading volume interprets information about transactions that occur in several periods of time in the Indonesia Stock Exchange or reflects stock trading activities on the stock exchange and reflects investors' investment decisions. This is related to one of the motivations of investors to conduct share sale and purchase transactions, namely income related to capital gains. Small trading volume indicates investors who are little or less interested in investing in the secondary market while large volumes indicate the number of investors and the many interests to conduct stock buying and selling transactions.

\subsubsection{Effect of Market Capitalization on Investor Psychology}

The results of hypothesis testing the effect of market capitalization on investor psychology show a $\mathrm{P}$ value of 0,000 when compared to the $\mathrm{P}$ cut-off value $(0.05)$ which is certainly smaller $(* * * \leq 0.05)$. The results concluded that there was a positive and significant effect of market capitalization on investor psychology.

Market capitalization provides an idea of the price of a company when it is sold on the market. This is used as a basis by investors to assist in analyzing how much a company grows. Large market capitalization is generally one of the attractions of investors in choosing stocks. The greater the market capitalization of a stock, the longer the investor will hold back its ownership, because investors assume that large companies will tend to be more stable from the financial side, the risk is smaller and have good prospects in the long run with the hope of a large return.

\subsubsection{Effect of Investor Psychology on Investment Behavior}

The results of data analysis show that there is a significant positive effect of investor psychology on stock investment behavior. The existence of this significant influence has been based on statistical testing, where the $\mathrm{P}$ value is known to be far from the cut-off value $(.003 \leq 0.05)$. The test number shows that investor psychology has a significant influence on investment behavior.

The interpretation of the results of this study shows that investor psychology greatly influences the investment decisions of investors in the Indonesia Stock Exchange. Therefore, the behavior of stock investment cannot be separated from investor psychology. Every decision made by an investor, buying, selling, maintaining or doing nothing is the result of his thinking about what makes the market work, the result of his investment philosophy.

\section{CONCLUSION}

Based on the results of testing that has been done, it can be concluded that stock prices, trading volume and market capitalization have a significant influence on investor psychology, and investor psychology is known to have a significant influence on stock investment behavior. 


\section{REFERENCES}

Ahmad, Kamaruddin. (1996). Dasardasar Manajemen Investasi. Rineka Cipta, Jakarta

Alwi, Iskandar. (2003). Pasar Modal : Teori dan Aplikasi. Nasindo Internusa, Jakarta

Ang, Robert. (1997). Buku Pintar Pasar Modal Indonesia. Media Staff Indonesia, Jakarta

Ardiansyah. (2012). Analisis Pengaruh Faktor Fundamental dan Nilai Kapitalisasi Pasar Terhadap Return Saham. Jurnal Ilmiah Mahasiswa FEB Universitas Brawijaya Vol.1, No.2 : Semester Genap 2012/2013.

Arikunto, Suharsimi. (2001). Prosedur Penelitian: Suatu Pendekatan Praktek. Rineka Cipta, Jakarta

Arikunto, Suharsimi.. (2010). Prosedur Penelitian Suatu Pendeketan Praktik. Edisi Revisi 2010. Cetakan Keempatbelas. PT Rineka Cipta, Jakarta

Block dan Hirt. (2008). Foundation of Financial Management. The McGraw Hill, New York

Cahyono, Jaka. (2001). Menjadi Manajer Investasi Bagi Diri Sendiri. Gramedia, Jakarta

Cheng F Lee, G. M. (2001). Stock Expected Return and Volatility on China's Stock Market. Journal of Finance No 24 : 523-543.

Chordia, T. Subramanyam dan Ashuman. (2001). Trading Activity and Expected Stock Returns. Journal of Financial Economics, No.59: 3-32

Christanti dan Mahastanti. (2011). Faktor - Faktor Yang Dipertimbangkan Investor Dalam
Melakukan Investasi. Jurnal Manajemen Teori dan Terapan I Tahun 4 No.3, Desember.

Dachlan, Usman. (2014). Panduan lengkap Struktural Equation Modeling. Lentera ilmu, Semarang

Daniel,K.D. (1998). Investor Psychology and Security Market Under and Over Reactions. Journal of Finance No.53 : 1839-1885.

Darmadji. (2001). Pasar Modal di Indonesia. Salemba Empat, Jakarta

Desmond, Wira. (2011). Analisis Fundamental Saham. Exceed Books, Jakarta

Divisi Edukasi. (2016). Sekolah Pasar Modal bursa Efek Indonesia Level 1. Bursa Efek Indonesia, Jakarta

Edianto Ong. (2011). Technical Analysis for Mega Profit. Mega Offset Jakarta

Fakhruddin, Hendy. (2008). Istilah Pasar Modal A-Z. Jakarta : Elex Media Komputindo.

Fama, Eugene dan Kenneth. (1995). Size and Book to Market Factors in Earnings and Returns. Journal of Finance, Vol LI : 131-155.

Ferdinand, Augusty. (2000). Structural Equation Modeling : Aplikasi Model-Model Rumit Dalam Penelitian untuk Tesis S-2 \& Disertai S-3. Badan Penerbit Universitas Diponegoro, Semarang

Foster, G. (1986). Financial Statement Analysis (Second ed.). New Jersey: Prentice Hall Inc.

Handani, Emrizal. (2002). Analisis Pengaruh Stock Split Terhadap 
Likuiditas Saham Dilihat dari Volume Perdagangan Saham di Bursa Efek. Skripsi FE UNS, Jakarta

Husein, Umar. (2005). Metode Penelitian. Salemba Empat, Jakarta

Imad, M. a. (2009). Modelling The Behaviour Of Technicians And Fundamentalists In The Shanghai Stock Market. International Journal of Banking and Finance, 6.

Indriyo dan Basri. (1988). Manajemen Keuangan. BPFE, Yogyakarta

Jauhari, Rusman Budi dan Basuki. (2004). Analisis Fundamental Terhadap Return Saham Pada Periode Bullish dan Bearish Indeks Harga Saham Gabungan. Jurnal Akuntansi dan Keuangan Vo.9 No.2. Lampung

Jogiyanto, Hartono. (2004). Teori Portofolio dan Analisis Investasi. Edisi Keempat. BPFE, Yogyakarta

Jogiyanto, Hartono. (2008). Teori Portofolio dan Analisis Investasi. Edisi Kelima. BPFE, Yogyakarta Karpoff, J.M. (1986). A Theory of Trading Volume. Thw Journal of Finance no.41:1069-1087.

Latan, hengky. (2013). Model Persamaan Struktural Teori dan Implementasi Amos 21.0. Penerbit Alfabeta, Bandung

Maknun, Lu'luil. (2010). Analisis Pengaruh Frekuensi Perdagangan, Volume Perdagangan, Kapitalisasi Pasar dan Trading Day Terhadap Return Saham Pada Perusahaan Manufaktur Yang Terdaftar Di
BEI Periode Tahun 2006-2008. Skripsi. FE UNDIP, Semarang Malhotra, N.K. (2007). Marketing Research: An Applied Orientation. New Jersey: Pearson Education.

Margono. (2004). Metodologi Penelitian Pendidikan. Rineka Cipta, Jakarta

Martono dan Harjito. (2002). Manajemen Keuangan. Ekorisia, Yogyakarta

Masassya,Elvyn. Perilaku Investor. Kompas 19 April 2015, Jakarta.

Masassya,Elvyn. Psikologi Investasi. Kompas 31 Mei 2015, Jakarta.

Musdalifah, Azis. (2012). Analisis Fundamental dan Teknikal Melalui Expected Return dan Psikologi Investor Terhadap Perilaku Investasi Saham Di Bursa Efek Indonesia. Disertasi. Universitas Hasunuddin Makassar Natarsyah, Syahib. (2000). Analisis Pengaruh Beberapa Faktor Fundamental dan Resiko Sistematik Terhadap Harga Saham: Kasus Barang Konsumsi Yang Go-Public di Pasar Modal Indonesia. Jurnal Ekonomi Bisnis Indonesia, vol.15, no. 3 : 2941312.

Nofsinger, Jhon R. (2005). Psychologi of Investing. Second Edition. New Jersey : Precentice-Hall Inc.

Priyatno, Duwi. (2012). SPSS 20 Pengolah Data Terpraktis. Andi, Yogyakarta

Priyatno, Duwi. (2013). Mandiri Belajar Analisis Data Dengan SPSS. Mediakom, Jakarta

Ritter, Jay R. (2003). Behavioral Finance. Pacific-Basin Journal. No.11 : 429-437. 
Roscoe dikutip dari Budjiono. (2005). Metode Penelitian Bisnis. Salemba Empat, Jakarta

Roth, Allan S. (2007). Behavioral Finance. Article Wealth Logic. LLC.

Santoso, Singgih. (2011). Structural Equation Modeling (SEM) : Konsep dan Aplikasi Dengan AMOS 18. Elex Media Komputindo, Jakarta

Santoso, Singgih. (2014). Konsep Dasar dan Aplikasi SEM degan AMOS $22+C D$. Elex Media Komputindo, Jakarta

Sharpe, William F., Alexander, Gordon J., dan Bailey, Jeffery V. (1997). Investasi. Edisi Bahasa Indonesia, jilid 2. Diterjemahkan oleh: Njooliangtik, Hendry., dan Agustiono. PT. Prenhallindo, Jakarta

Silviyani,dkk. (2014). Pengaruh Likuiditas Perdagangan Saham dan kapitalisasi Pasar Terhadap Return Saham Perusahaan yang Berada Pada Indeks LQ $45 \mathrm{Di}$ Bursa Efek Indonesia Periode 2009-2013 (Studi Empiris Pada Perusahaan LQ 45 Di Bursa Efek Indonesia). E-Journal S1 Ak Universitas Pendidikan Ganesha Jurusan Akuntansi, Vol. 2 No.1.

Slovic, paul. (1972). Psychology Study of Human Judgment: Implication for Investment Decision Making. Journal of Finance, Vol.27 : 779799.

Sugiyono. (2001). Metode Penelitian Kuantitatif, Kualitatif dan $R \& D$. Penerbit Alfabeta, Bandung
Sugiyono. (2008). Metode penelitian pendidikan: Pendekatan kuantitatif, kualitatif, dan $R \& D$. Alfabeta, Bandung

Sulistiawan dan Liliana. (2007). Analisis Teknikal Pada Perdagangan Sekuritas. ANDI, Jakarta

Supardi. (2005). Metodologi Penelitian Ekonomi \& Bisnis. Yogyakarta: UII Press Yogyakarta.

Susanto, Djoko \& Sabardi. Agus. (2002). Analisis Teknikal di Bursa Efek. STIM-YKPN Press, Yogyakarta

Teguh, P. (2000). Analisa Rasio Keuangan dan Nilai Kapitalisasi Pasar sehagai Prediksi Harga Saham di BEI Pada Periode Bulish dan Bearish. Simposium: Nasional Akuntansi III. Jakarta.

Venkatesh, C., \& Madhu Tyagi and Ganesh, L. (2012). Fundamental Analysis and its Usage in Indian Capital Markets: A Survey. Research Publications Journal 7(1) : 46-54, Bangladesh

Vibby, Santo. (2007). Jual Saham Anda Lebih Mahal. Vibby Publishing, Jakarta

Warren Tease. (1993). The Stock Market and Investment. OECD Economic Studies No.20. Spring.

Wijaya, Johanes Arifin. (2002). Bursa Berjangka. ANDI, Yogyakarta

Yosef S, Bar \& L.D Brown. (1977). A Examination of Stock Splits Using Moving Beta. Journal of Finance No.32 1069-1080. 